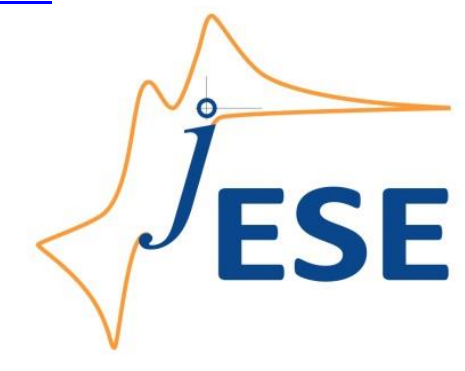

Open Access: ISSN 1847-9286

www.jESE-online.org

Book review

\title{
Review on ELECTROCHEMISTRY, A GUIDE FOR NEWCOMERS by Helmut Baumgärtel
}

\author{
Abdul Hasib ${ }^{\bowtie}$ \\ Kazipur Government Mansur Ali College, Kazipur-6710, Sirajgonj, Bangladesh \\ 82abdulhasib@gmail.com
}

Received: February 25, 2021; Accepted: May 19, 2021; Published: May 23, 2021

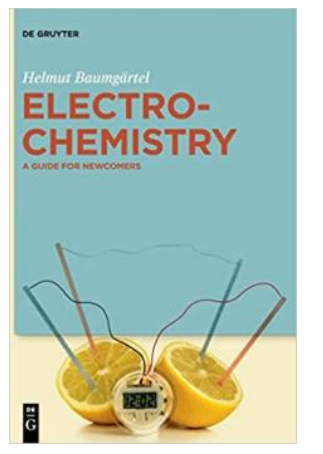

\author{
ELECTROCHEMISTRY \\ A GUIDE FOR NEWCOMERS \\ by Helmut Baumgärtel \\ Walter de Gruyter GmbH, Berlin/Boston, Oct. 2019 \\ Hardcover: 230 pages \\ ISBN 978-3-11-044340-0 \\ e-ISBN (PDF) 978-3-11-043739-3 \\ e-ISBN (EPUB) 978-3-11-043554-2
}

In his Nobel lecture 2001, K. Berry Sharpless said: "When I started doing chemistry, I did it the way I fished - for the excitement, the discovery, the adventure, for going after the most elusive catch imaginable in uncharted seas" [1]. True, in electrochemistry, a subject considered by many as an apparently boring and complex one, there are the "seas"- electron-sea in metals, electrolytic solutions and the "fishes"- moving electrons, ions, ionophores and so on. Then, this masterpiece by Professor Helmut Baumgärtel may be cited as a good example amongst a few of the same genre that would retain the readers of a deeper subject in an engaging way like fishing in the "electron-sea".

The book as are paraphrased from p. 1 and p. 2 is written in an "up-to-date, understandable and systematic way" (p. 1) following all through pedagogical style. It is aimed primarily for those who "are not familiar with electrochemistry but are interested in it" (preface). They may be engineers, physicists, schoolteachers making use of electrochemistry in their respective professions or any interested individual making a way to electrochemistry through the "self-study" (p. 1). And this book is dedicated to you if you are one of the amongst those who "want to know the story behind energy storage as reported in daily newspapers" (preface).

In its content organization, it may be compared to some other books [2] with respect to that there are only three core chapters, total absence of chapter-end practice questions, and only a 
limited well-chosen worked-out mathematical examples. All these must be taken to be granted as per the declaration in the preface, "this book is not a textbook in the general sense". Thereby, in lieu of arranging the contents according to the traditional choice of most student-friendly text books, the author tries to construct a conceptual framework about the much complex topics that he expects to be discerned by his readers. And, it is one of the goals of this book (p. 2) that is, to psychup the newcomers to deal with the arising confusions in their psyche.

In the chapter two "Fundamentals", the author has begun with a simple reaction of zinc rod dipped into a copper sulphate solution describing, in a simple story-telling manner, various situations and conditions that has resulted in establishing an electrochemical cell (p. 12). After that, the discussion culminated in the various types of cells and one might easily be intrigued along the way by the step-by-step approach in developing an experimentally verified scientific account. Then, the thermodynamic aspects of equilibrium potential have been enumerated with complex mathematical derivations. The equations and derivations connected with the Debye-Hückel model, double layer models, current-overpotential relationship, the Tafel behavior of the overpotential, mass transfer by diffusion - all these to name a few, might not be so easy to catch thoroughly. In such instances, for a deeper understanding the author suggests: "it is necessary to study all the details.........." (p. 2). Additionally, most of such derivations lack detail stepwise work-out. Skipping the middle lines in complex derivations is perhaps a reasonable choice by the author who either has constraint to curb the size of his booklet as mentioned in many occasions (p. 110, p. 158, p. 165) or has left the trifles for us to be dealt with. However, any ambitious reader may be well satiated with appendices " $A$ " to " $G$ " where many complex calculations have been carried out in details. Indeed, much of the mathematical portions of the chapter two has comprised topics that are likely wellsuited only for the advanced readers.

A thorough illustration of a "unique principle" to study an electro-chemical system, that is; "we send a controlled input into the system and measure the response of that system" (p. 111) is the core focus of the chapter three, "Practical work in electrochemistry". Hence, different types of currenttime curves, current-potential curves, cyclic voltammograms with respect to various experimental methods have predominately occupied the major parts of this chapter. A beginner might strive to cope with the subtle differences amongst the reversible and irreversible cyclic voltammetry (p. 132), the CE, EC and ECE mechanisms of various chemical reactions (p. 139) and so forth, yet if explored, this chapter would certainly provide the must-have ideas about different electrochemical set-up and the methods to investigate into them.

The last chapter "Applications of electrochemistry" would appeal the readers most as there are the topics either we face those in our day-to-day experiences from various batteries to corrosion or, from routine laboratory course work to large scale industrial production we are to deal with.

For it is seen a topic be started very occasionally with the conventional approach to define that at first, it seems that the author has a deliberate choice of scattering the so called memorisable statements elsewhere in the text e.g., the most conventional definition pertaining to electrochemistry appears in the last line of the first chapter (p. 9). The likewise occurrences happen all through the book whereupon any avid reader should ferret out the so-called definitions and/or terminologies. However, scholarly literature suggests that there is an utmost significance of making formal definitions through learning processes not only in the child learners but also in the scientists [3].

The thermodynamic aspects of electrochemistry have been whenever possible favorably spaced throughout the book. Owing to this, any newcomer may find some basic chemical aspects like detail reactions of numerous types of cells, cell EMF determination, salt bridge, etc. to be overshadowed. 
Albeit they have been dealt with either, this kind of favor is much expected from the author who is a veteran professor of physical chemistry in an eminent university in Berlin, Germany.

The use of the boxes with "twofold intension" as is claimed in the introduction (p. 2) is much appreciated but, throughout the book those useful boxes are only five in numbers: such a paradoxical happening is beyond our expectation. If there were more such boxes, they would undoubtedly have helped the readers more. There are a few mathematical worked out problems but no numerical exercises that can easily be substantiated from the modern teaching-learning perspectives for example, "chemistry teaching is polluted and ultimately compromised in its goal by numerical exercises..... such elementary mathematics do not give a clue as to the real understanding of chemical notions by one's students" [4] and our present author is well aware of that.

Let's be prepared for an excursion guided by the author who, by his briefings like "the next step of our experimental excursion is to connect the electrodes via a low resistance line " (p. 13) would for sure rejuvenate the young minds. Such an approach, "to instruct into mainstream chemistry and to lead students into excursions outside of mainstream chemistry" is corroborated, amongst many by Laszlo [5].

Now, it's time to start the experimental excursion in the way of electrochemistry and this book would certainly guide the beginners the right way! And for the libraries, it would certainly be a valuable one.

\section{References}

[1] Wikiquote, https://en.wikiquote.org/wiki/K. Barry Sharpless (date accessed, 15 Feb. 2021).

[2] C. M. A. Brett, A. M. Oliveira-Brett, Electrochemistry: Principles, Methods, and Applications, Oxford University Press, Oxford, UK, 1993. ISBN 0198553897 (Hardback).

[3] M. A. Iris, B. E. Litowitz, M. W. Evens, International Journal of Lexicography 1(3) (1988) 238-252 https://doi.org/10.1093/ijl/1.3.238.

[4] K. J. Smith, P. A. Metz. Journal of Chemical Education 73(3) (1996) 233 https://doi.org/10.1021/ed073p233.

[5] P. Laszlo, Science and Education 22 (2013) 1669-1706 https://doi.org/10.1007/s11191-011-9408-6.

C 2021 by the authors; licensee IAPC, Zagreb, Croatia. This article is an open-access article distributed under the terms and conditions of the Creative Commons Attribution license (https://creativecommons.org/licenses/by/4.0/) 